\title{
24. B. Nihan Eren'in Kör Pencerede Uyuyan adlı öykü kitabı üzerine bir inceleme
}

\section{Mustafa KARADENİ'}

APA: Karadeniz, M. (2021). B. Nihan Eren’in Kör Pencerede Uyuyan adlı öykü kitabı üzerine bir inceleme. RumeliDE Dil ve Edebiyat Araşttrmaları Dergisi, (23), 369-380. DOI: 10.2900o/rumelide.948993.

\section{Öz}

Çağdaş Türk öykücülüğünün genç yazarlarından biri olan B. Nihan Eren’in Kör Pencerede Uyuyan adlı öykü kitabı, bilinçle kurgulanmış ve birbirine sıkıca bağlı yirmi öyküden oluşur. "Gece" ve "Gün” adlı iki bölümden oluşan kitaptaki öyküler, ortak bir zaman diliminde ve mêkanda geçer. Aynı zaman ve mekân üzerine kurgulanan öyküler, birbiriyle kesişerek birbirine işaret ederek ve birbirini aydınlatarak gelişir. Öykülerin içerdiği bu özellik, Kör Pencerede Uyuyan'a bir romandaki gibi bütünlüklü bir yapı da kazandırır. Başka öykücülerde sadece atmosfer oluşturmak için kullanılan nesne veya ayrıntılar, Eren’in öykülerinde olay örgüsünü aydınlatan bağlantı noktaları olarak işlev kazanır. Kitaptaki öykülerde yalnız, mutsuz, kaygılı, umutsuz, geçmişinde hayal kırıklıklarını ve terk edilmişlikleri barındıran muhtelif yaş gruplarına ait insanlarla karşılaşılır. Eren, aynı toplumsal yapı ve zaman diliminde yaşama tutunmaya çalışan "kırık hayatlar"dan manzaralar sunar. Bu manzaralar yoluyla, öykü karakterlerinin yaşadıklarının aslında toplumsal yapıya hâkim olumsuzluklardan kaynaklandığını ima etmeye çalışır. Kitaptaki öykülerde görünüşle gerçek arasındaki derin uçurum ve topluma hâkim ikiyüzlülük Eren'in eleştiri oklarının temel hedefi olur. Eren’in öykülerindeki bu kurgu ve içerik uyumu, dil ve anlatım tutumuyla da desteklenir. Kör Pencerede Uyuyan adlı öykü kitabına yönelik biçim, kurgu, dil ve muhteva eksenli bir inceleme bu makalenin temel konusunu oluşturmaktadır. Bu inceleme yoluyla Eren’in öykü anlayışının temel bileşenlerini ve bunların birbiriyle olan ilişkisini saptamaya çalışmak amaçlanmıştır.

Anahtar kelimeler: Kör Pencerede Uyuyan, öykü, kurgu, muhteva, dil ve anlatım

\section{A study on B. Nihan Eren's storybook Sleeping in the Blind Window}

\begin{abstract}
One of the young writers of contemporary Turkish storytelling, B. Nihan Eren's short story book, Sleeping in the Blind Window, consists of twenty stories that have been constructed with consciousness and are tightly connected to each other. The stories in the book, which consists of two parts named "Night" and "Day", take place in a common time and place. Stories built on the same time and space develop by intersecting each other, pointing to each other and enlightening each other. This feature of the stories gives Sleeping in the Blind Window a holistic structure like in a novel. The objects or details used solely to create atmosphere in other storytellers function as connecting points that illuminate the plot in Eren's stories. In the stories in the book, people from various age groups are encountered, who are lonely, unhappy, anxious, hopeless, and harbor disappointments and abandonments in their past. Eren presents scenes from "broken lives" trying
\end{abstract}

Dr. Öğr. Üyesi, Batman Üniversitesi, Fen Edebiyat Fakültesi, Türk Dili ve Edebiyatı Bölümü (Batman, Türkiye), gulderim@hotmail.com, ORCID ID: oooo-0002-4833-0207 [Araştırma makalesi, Makale kayıt tarihi: 31.03.2021-kabul tarihi: 20.06.2021; DOI: 10.29000/rumelide.948993]

Adres

RumeliDE Dil ve Edebiyat Araşttrmaları Dergisi Osmanağa Mahallesi, Mürver Çiçeği Sokak, No:14/8 Kadıköy - ÍSTANBUL / TÜRKIYE 34714 e-posta: editor@rumelide.com tel: +90 $5057958124,+902167730616$

\section{Address}

RumeliDE Journal of Language and Literature Studies

Osmanağa Mahallesi, Mürver Çiçeği Sokak, No:14/8

Kadıköy - ISTANBUL / TURKEY 34714

e-mail: editor@rumelide.com,

phone: +90 505 7958124, +90 2167730616 
to hold on to life in the same social structure and time period. Through these landscapes, she tries to imply that what the story characters experience actually stems from the negativities dominating the social structure. The deep gap between appearance and reality and the hypocrisy that prevails in society in the stories in the book are the main targets of Eren's criticism arrows. This fiction and content harmony in Eren's stories is also supported by the language and narrative attitude. The main subject of this article is an analysis of the story book Sleeping in the Blind Window on the basis of form, fiction, language and content. Through this analysis, it is aimed to determine the basic components of Eren's understanding of the story and their relationship with each other.

Keywords: Sleeping in The Blind Window, story, content, language and expression

\section{Giriş}

Çağdaş Türk öykücülüğünün genç yazarlarından biri olan B. Nihan Eren (1981 - ...), akademik uğraşlar ve senaryo yazarlığıyla geçen iş yaşamının içinde, adını Adam Öykü, Notos, Kitap-llk ve Askıda Öykü gibi dergilere gönderdiği öykülerle duyurduktan sonra, ilk öykü kitabını 2008 yılında Yavaş adıyla yayımlar. Bir ilk kitap olmasına rağmen, gerek kurgusunun gerekse özenli dil ve anlatım tarzının içerdiği ustalıkla Yavaş, taşraya ve taşra insanının yaşantısına odaklanan öyküler içerir (Tosun, 2008: 137). Sinematografik bir yapının idaresinde gelişen kitaptaki on dört öykü, ortak bir zamana, mekâna ve yer yer şahıs kadrosuna yaslanır. Yavaş’ta "[k]öşeye sıkışmış, kenarda kalmış, kimsenin önemsemediği insanları ele alan yazar, ilginç metaforları ve gözlem gücünü ayrıntılara odaklamasıyla tekdüzeliğe düşmeden özgünlüğü yakala[r]” (Koyuncu, 2019). Yavaş genç bir yazarın yayımlanan ilk öykü kitabı olmasına rağmen dili ve kurgulama tarzıyla edebiyat ortamında dikkat çeker.

Yazarın ikinci öykü kitabı Kör Pencerede Uyuyan 2015 yllında yayımlanır. İlk öykü kitabı Yavaş’a nazaran kurgu ve atmosfer olarak daha "derin" ve "olgun” öyküler ihtiva ettiği, ikinci kitap hakkında yapılan yorum ve değerlendirmelerin ortak noktası olarak öne çıkar. Söz gelimi Işıl Çobanlı, kitapla ilgili yazısında bağlama ilişkin olarak şu değerlendirmelerde bulunur:

"Kör Pencerede Uyuyan yazarın ilk kitabına göre derinlikli duyguların, daha olgun yaklaşımların kurgulandığı bir birikim olmuş. Çocukluktan yaşlılığa, kadın ve erkek ilişkilerinden yalnız kadınlara ve yalnız adamlara uzanan bu geniş alanda görünen, başlı başına hayat. Yazar, bu kitabında ev, aile ve sokak yaşantısındaki karakterlerin yaşadıklarına dair çok denk benzetmeler, tasvirler ve kurgularla karşımıza çıkıyor. Bu nedenle iki kitap arasında sekiz sene beklediğimiz için üzülmüyor, seviniyoruz" (Çobanll, 2015).

Nitekim ele aldığı konuyu değişik açılardan ve işlenmiş bir dille geliştirme konusundaki başarısından dolayı kitap Ferit Edgü, Nursel Duruel, İbrahim Yıldırım, Handan İnci ve Faruk Duman'dan oluşan jüri tarafından 2015 Cevdet Kudret Edebiyat Ödülü’ne değer görülür.

Hayal kırıklıkları ve pişmanlıklara rağmen yeni bir başlangıç umudunu bir kadınla erkek dolayımında odağına alan Hayal Otel ise beş yıl aradan sonra, 2020 yılında -ilk iki kitap gibi- Yapı Kredi Yayınları tarafından yayımlanır. Eren’in öykücülüğünün kat ettiği mesafeyi enikonu işaretleyen bu son kitap dil, biçim ve kurgu olarak Kör Pencerede Uyuyan'ın devamı ve bütünleyicisi olarak görülebilir. Mualla Uçmaner’in, iki kitabın sahip olduğu rafine ve ölçülü dile işaret ederek başladığı değerlendirmesi şöyle devam eder:

"Biçim olarak ise ikinci öykü kitabı olan Kör Pencerede Uyuyan ile aynı yoldan gittiğini söylemek mümkün Eren’in. Yani birbirini tamamlayan öykülerle örülü bir kitap kurgulamış. Bir öykünün bittiği yerden bir diğeri başlıyor, bir önceki öykü kaldığı yerden devam etmiyor, yeni devam

\begin{tabular}{r|l} 
Adres & Address \\
RumeliDE Dil ve Edebiyat Araşttrmalar Dergisi & RumeliDE
\end{tabular} Jarnal of Languge and Literature Studies Kadiköy - ISTANBUL / TURKIYE 34714 e-posta: editor@rumelide.com tel: +90 505 7958124, +90 2167730616
Osmanağa Mahallesi, Mürver Çiçeği Sokak, No:14/8

Kadıköy - ISTANBUL / TURKEY 34714

e-mail: editor@rumelide.com,

phone: +90 5057958124 , +90 2167730616 
hikâyeleri okumuyoruz belki ama sonuç olarak bir bütünlüğe hizmet ediyor tüm metinler. Öte yandan her öykü kendi başma da anlam taşıyor, bir edebi hazzı uyandırıyor. Fakat Eren, ilkin Kör Pencerede Uyuyan ile deneyimlediği bu romanı da anımsatan yapı ile bir anlamda kendi yazın karakteristiğini meydana getirmişe benziyor. Az önce de dile getirildiği gibi devam hikâyesi gibi okuduğumuz bir yapı değil bu. Birbirinden bağımsız da kendi vücutlarını oluşturabilen öyküler olmakla birlikte, romanesk bir çatı altında da toplanabiliyorlar yalnızca” (Uçmaner, 2020).

Uçmaner, kitaptaki öykülerin hem tekil olarak sahip olduğu kurgusal ve anlamsal bütünlüğe hem de birbirine ulanarak oluşturduğu romanesk yapıya işaret ederek Eren’in kurgulama konusundaki özgünlüğü dile getirir. Kör Pencerede Uyuyan'la Hayal Otel kitapları arasındaki dil, kurgu ve yapı benzerliği tematik koşutluklarla da desteklenir. Bu koşutlukları Eren, ilk kitapla olan farklılıklar üzerinden şöyle dile getirir:

\begin{abstract}
“Taşranın merkezden uzaklığını, dolayısıyla pek çok yenilikten esirgenmişliğini ve 8o'lerde buralardaki dönüşümü, oranın topografyasını anlatmak istiyordum ama bunu toplumcu gerçekçi bir tondan yapmayı da arzu etmiyordum. Bu yüzden Yavaş’ta aşkın, çocukluğun, deliliğin, toplumsal yapının masalsı bir karşılı̆̆ı olmuş olabilir. Fakat ötekiler için bunu söyleyemeyeceğim. Hem Kör Pencerede Uyuyan hem de Hayal Otel'de gerek içerikte gerek dilde gerçekçiliği yakalamaya çalıştığımı, karakterlerin ve hayatın belli bir bütününün adeta fotoğrafını çekmeye çalıştı̆̆ımı söyleyebilirim” (Toprak, 2020).
\end{abstract}

Yavaş'taki daha bireysel ve masalsı atmosfer, takip eden diğer iki kitapta dil ve içerik bakımından görece bir değişime uğrar. Kör Pencerede Uyuyan ve Hayal Otel'de yazar, gerek dil gerekse içerik bakımından daha gerçekçi bir tutumu esas alır. Bu paralelde gündelik yaşamın muhtelif kesimlerinden seçilen karakterler yoluyla bütünlüklü bir toplumsal manzara sunulmaya çalışılır.

Söylenenlerden de anlaşılabileceği üzere Eren, öykülerinin sahip olduğu dil, kurgu, biçim ve muhteva özellikleriyle özgün bir öykü evreni kurmaya çalışır. Bu öykü evreninin ağırlık merkezini anlaşılabildiği kadarıyla yazarın ikinci öykü kitabı Kör Pencerede Uyuyan oluşturmaktadır. Bu bağlamda ilk kitap olan Yavaş, Kör Pencerede Uyuyan için bir hazırlık, Hayal Otel adlı son kitap ise ulaşılan ustalığı ısrarla işaretleyen bir durak olarak değerlendirilebilir. Bu açılamalar ışığında B. Nihan Eren’in Kör Pencerede Uyuyan adlı öykü kitabına yönelik biçim, kurgu, dil ve muhteva eksenli bir inceleme bu makalenin temel konusunu oluşturacaktır. Bu inceleme yoluyla Eren’in öykü anlayışının temel bileşenleri ve bunların birbiriyle olan ilişkisi saptanmaya çalışılacaktır.

\title{
1. Zaman ve mekân üzerinden kesișen hayatlar
}

Gaston Bachelard, Uzamın Poetikası adlı kitabında, fenomenolojik bir okuma tavrının okurun içinde bir okuma gururu oluşturarak onda yazarın üretim sürecine katılmak konusunda bir yanılsama uyandırdığını söyledikten sonra böyle bir tavra ulaşabilmenin temel yordamına şu cümlelerle işaret eder:

"Böyle bir tavıra, yaptığımız ilk okumada kesinlikle varamayız. İlk okuma fazla edilgenlik içerir. Okur ilk okumada bir çocuktur biraz, okuyarak oyalanan bir çocuk. Ne var ki bitirir bitirmez her iyi kitabı yeniden okumaya koyulmak gerekir. Eskiz denilen ilk okumadan sonra, gerçek okuma uğraşı gelir" (Bachelard 2008: 59).

B. Nihan Eren’in insana ilişkin görünüm ve nesnelerin idaresindeki Kör Pencerede Uyuyan² adlı öykü kitabı, gerek kurgusu ve içeriği gerekse dil ve anlatım tavrıyla dikkatle okunmayı gerektiren bir

2 İnceleme nesnesi olan kitaptan yapılacak alıntıların sıklı̆̆ göz önüne alınarak öykü adı ve sayfa numarasının verilmesiyle yetinilecektir. Alıntılar Kör Pencerede Uyuyan'ın şu baskısındandır: Eren, B. N. (2015). Kör Pencerede Uyuyan. İstanbul: Yapı Kredi.

RumeliDE Dil ve Edebiyat Araştırmaları Dergisi Osmanağa Mahallesi, Mürver Ciçeği Sokak, No:14/8 Kadıköy - ISTANBUL / TÜRKIYE 34714 e-posta: editor@rumelide.com tel: +90 505 7958124, +90 2167730616
Address

RumeliDE Journal of Language and Literature Studies

Osmanağa Mahallesi, Mürver Çiçeği Sokak, No:14/8

Kadıköy - ISTANBUL / TURKEY 34714

e-mail: editor@rumelide.com,

phone: +90 505 7958124, +90 2167730616 
yoğunluk ve örgüye sahiptir. Bu özellikleriyle kitabın, Bachelard'ın işaret ettiği türden bir okuma uğraşı için ilk okumadan daha fazlasını talep edebileceğini söylemek mümkün.

Kör Pencerede Uyuyan adlı öykü kitabının, her şeyden önce, bilinçle kurgulanmış ve birbirine sıkıca bağlı öykülerden oluştuğunu belirtmek gerekir. "Gece" ve "Gün" adlı iki bölümden oluşan kitapta toplam yirmi öykü bulunmaktadır. Her bölümde yer alan öyküler, ortak bir zaman diliminde ve mêkanda geçer. Eren, ortak bir zaman ekseninde gelişen bu kurguyu bile isteye tasarladığını "Kör Pencerede Uyuyan'da takıntılı olduğum mesele zamandı. Bu yüzden karakterleri tek bir gecede ve tek bir günde birleştirdiğim öyküler yazdım.” (Toprak, 2020) cümleleriyle doğrudan dile getirir. Yazar, dayandığı yapısal ortaklık konusunda sadece zaman unsuruna işaret etse de kitaptaki öyküler aynı zamanda ortak bir mekânı da paylaşır. Bölüm adlarının da işaret ettiği üzere, kronolojik olarak, ilk bölümdeki on bir öykü bir geceye, ikinci bölümdeki dokuz öykü ise bir gündüze ilişkindir. Öyküler, vaka zamanı itibariyle dar bir aralıkta geçer, ortak anlar/kesitler üzerine kurulur. Her bölümün ilk öyküsü, bir çerçeve öykü işlevi görür. Bu bağlamda "Gece"deki öyküler, bölümün ilk öyküsü olan "Kaçak Çay" ın içine sığdırılabilecek eşzamanlı bir anlatıma sahiptir. Bölüm boyunca anlatılan olay ve durumlar bu öykünün içine yerleşir. İlk beş öyküde geceye doğru ilerleyen zaman dilimi, öykü kişilerinden biri olan Tahir'in sokak ortasında bir serserinin kurşunuyla öldürülmesiyle belirginleşir ve bütün öyküleri bu olayın yaşandığı ana bağlar. "Portakal”dan, altıncı öyküden itibaren bütün öyküler, Tahir’i öldüren silah sesiyle noktalanır.

"Gün” bölümündeki öyküler de benzer bir seyir izleyerek, "Top” adlı ilk öykünün içerdiği mekân ve zamanın ekseninde gelişir. Denize nazır bir tatil beldesinde, muhtelif insanların ana ve geçmişe ilişkin duygu ve düşünceleri, yine çok kısa bir zaman aralığında geçer. Bütün öyküler, ilk bölümdeki gelişime paralel şekilde, anlık bir olayla noktalanır. Birden esen bir rüzgârla beraber denizin içeri doğru çekilmesinin yarattı̆̆ telaş (Çeken akıntı!), bütün öyküleri, aynı sona bağlayarak kurguda bir bakışımlılık, öykü kişilerinin yaşamlarında ise âdeta gizli bir ortaklığa zemin hazırlar.

Eren’in öykülerinin kurgulama tarzındaki özgünlük bununla da sınırlı kalmaz. Her öykü, önceki veya sonraki öykülere bilinçli bir şekilde bağlanır. Öykülerin aynı zaman ve mekân üzerine inşa edilmesi, bu kesişime imkân sağlar ama, bunun ustaca ve pek çok yerde sezdirilerek yapıldığı görülür. Eren, okuruna dikkat ve çaba talep eden bir kurgu sunar. Kitabın ilk öyküsü olan "Kaçak Çay”da bir yalanın yorgunu Melike ve mühendislik öğrencisi umarsız Ilgaz’n yaşantıları, peş peşe kesitlerle okura aktarılır. Birbirinden yalıtık ve kopuk gibi sıralanan bu sahneler, Melike'nin apartman komşusu gebe Meryemana'yı doğum sancıları başlayınca bir taksiyle hastaneye yetiştirme telaşı içindeyken Ilgaz’n bindiği otobüsün yanlarından geçmesiyle birbirine bağlanır:

"Kadın Melike'nin avcunu öyle bir sıktı ki tırnakları etine geçti. Avcundaki yıldız... Taksici "Bu ne şimdi? Bir doğum daha mı var nedir?” deyip gene güldü. Cevap vermediler. Bir otobüs yanlarından geçti. Ilgaz başını cama yaslamış, mide bulantısını bastırmaya çalışıyordu” (s. 16).

$\mathrm{Bu}$ kesişme anı, anlatıcının açık bir şekilde işaret ettiklerindendir. Ama öykülerde, Eren'in bu kesişmeleri çok daha örtük bir şekilde yaptığı birçok sahne de vardır. Bu durumu, hemen aynı sahnenin devamı üzerinden örneklemek mümkündür. Yukarıdaki pasaj, Melike için çok trajik olan bir olayla da kesişir. Anlatıcı, bunu alabildiğine örtük bir şekilde, taksicinin keyifli sözlerinin ve Meryemana'nın doğum sancılarının arasına gizler. Hastaneye doğru seyir hâlindeyken uzaktan duyulan siren sesi ve büyüyen sıkıntısı yoluyla, Melike'nin babasının öldürülmesi olayı da bu sahneye ve ana sarsıntısız bir geçişle eklemlenir:

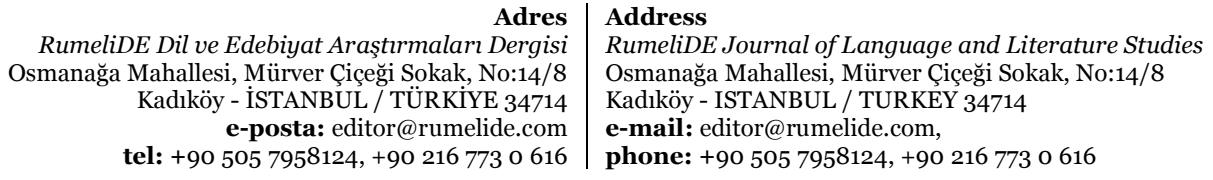

RumeliDE Dil ve Edebiyat Araşttrmaları Dergisi , Mürver Çiçegi Sokak, No:14/8 e-posta: editor@rumelide.com tel: +90 505 7958124, +90 2167730616
Address

Osmană̆

e-mail: editor@rumelide.com

phone: +90 $5057958124,+902167730616$ 
“Dar sokaklardan geçtiler, köşeleri döndüler. Uzaktan polis arabasının sireni duyuldu. Melike'nin sıkıntısı büyüdü. Şoför siren sesine de söylendi. "Bak daha sabahın körü, kimbilir gene n’oldu, memleketin iyice çivisi çıktı," dedi. Kadına çivi gibi bir acı daha saplandı. Eti kasılıp kalıyordu. "Nefes al" diye fisıldadı Melike. "Nefes almak zorundasın." Kadın nefes alamıyordu. Şoför, "Benim hanım ilkinde tam iki gün bas bas bağırdı ama üçüncüyü fırt diye çıkarttı, maşallah" deyip gevrek gevrek gülünce, Melike dışarı baktı. Onlar caddeye çıarken, bir ambulans sokağa dönüyordu. Melike bakakaldı. Rüyasında yıldızlar...” (s. 16).

Bu kurgulama mantığı, Eren’in bütün öykülerinin sathına yayılır. Her iki bölümdeki öyküler birbiriyle kesişerek birbirine işaret ederek ve birbirini aydınlatarak gelişir. Öykülerin sahip olduğu bu özellik, Kör Pencerede Uyuyan'a bir romandaki gibi kurgusal bir bütünlük ve organik bir birlik3 de kazandırır.

Öykülerin birbiriyle kesişmelerinin bölüm mantığıyla sınırlanmamış olması, okur nezdinde bu düşünceyi daha da pekiştirir. İlk bölümdeki öykülerden birine ait bir ayrıntı, eğer gözden kaçırılmazsa, ikinci bölümdeki öykülerden birine değer ve onu aydınlatır. Kitabın "Gece" bölümündeki "Ceviz" öyküsünde, söz gelimi, Meryemana’nın karnındaki çocukla kocası tarafından terk edilmesine ilişkin anımsamalar, küçük bir ayrıntı içerir. Sahne şöyledir:

“Anımsanan geçmiş. Geçmiş, geceleri uyutmuyordu. Meryemana belini doğrultamadı. Terliyordu. Avcunu açtı. Üzeri mavi şeritli beyaz bir bebek çorabı teki, buruşuk yatıyordu. Yolda bulmuşlardı. Balayındalarken, yazları insana uzun gelebilecek ağaçlıklı bir patikada, yürüyor, kumsala iniyorlardı. Meryemana denizden gelen esintinin kocasının kokusunu burnuna çarpmasıyla mest oluyor, martıların sesini duyabiliyordu" (s. 79).

Öykülerin birer laytmotif değeri taşıyan nesneler ağı içerisinde, sadece çocuk sahibi olma isteğine işaret ettiği düşünülebilecek bu küçük ayrıntı, "üzeri mavi şeritli beyaz bir bebek çorabı teki” (s. 79), öyküler arasındaki bağlantıların bölümler arası bir düzeye sıçramasını; ikinci bölümdeki "Krem" öyküsünde adı sanı bilinmeyen balayındaki çifti tanımayı ve bu tanışıklığın ışığında Meryemana'nın serencamını enikonu anlamayı sağlar. Bölümler arası teması sağlayan bu küçük ayrıntı, "Krem" öyküsünde şöyle belirir: "Karısı 'ah' dedi. Eğildi yerden bir şey aldı. Avcunu açıp muzip gösterdi. Bir bebek çorabı teki. Üzerinden mavi bir şerit geçmiş, yoldan geçerken bir bebek üzerinden düşürüvermiş. Bu da mı olacaktı? Sıradaki buydu.” (s. 104). Ama bu küçük ayrıntı, sadece Meryemana'nın durumunu aydınlatmaz. Bölümler arasındaki vaka zamanının birbirinden bir hayli uzak olduğuna da ışık düşürür. Başka bir deyişle, bölümler arasındaki zaman farkı, gün aşırıdır. Kitaptaki düzenin aksine, "Gün" bölümü, kronolojik olarak "Gece"yi takip etmez; ondan önceki bir zaman dilimine işaret eder. "Gece" bölümündeki öyküler, tersine bir kronolojik siralanma doğrultusunda "Gün" bölümündeki öykülerde anlatılanlardan çok sonra yaşanmış hayatları ve durumları anlatır. Tüm bunlar, bu küçük ayrıntıyla okura ayan olur.

“Çünkü öykü, öncelikle bir ayrıntı sanatıdır. (...) Öykücü küçük bir ayrıntıyla, sembolle âdeta bütün bir hayatı özetler. Öykücüler, küçük ayrıntılardan, büyük, kalıcı sonuçlar üretmeye çalışırlar. Küçük ayrıntılarla, göndermelerle bir anın gizemini (hayatı özetleyen o gizi) sıradan ânlarla sembolleştirirler" (Tosun, 2011: 252).

Başka yazarların öykülerinde sadece atmosfer oluşturmak için kullanılan nesne veya ayrıntılar, Eren’in öykülerinde kurguyu tümleyen, aydınlatan bağlantı noktaları işlevi kazanır. İncelikle örülen ve öykülerin kendi bütünselliğini bozmayan bu bağlantılar, ancak dikkatle okunduğunda fark edilebilir.

Berna Moran, Yeni Eleştiri geleneğinden mülhem "organik birlik" kavramını şu şekilde tanımlar: "Eserdeki her öğenin ve bağıntının eserin değeri için gerekli olması; gereksiz hiçbir öğenin ve bağıntının bulunmaması ve bunlardan her birinin yalnız kendi hesabına rol oynamakla kalmayıp diğerlerini de etkilemesi ile sağlanan düzene organik birlik denir" (Moran, 2007: 160).

RumeliDE Dil ve Edebiyat Araştırmalar Dergisi Osmanağa Mahallesi, Mürver Ciceĕgi Sokak, No:14/8 Kadıköy - İSTANBUL / TÜRKIYE 34714 e-posta: editor@rumelide.com tel: +90 $5057958124,+902167730616$
Address

RumeliDE Journal of Language and Literature Studies Osmanağa Mahallesi, Mürver Çiçeği Sokak, No:14/8

Kadıköy - ISTANBUL / TURKEY 34714

e-mail: editor@rumelide.com,

phone: +90 $5057958124,+90216773$ o 616 


\section{Kurık hayatlar geçidi}

Kör Pencerede Uyuyan'daki öyküler içerik olarak yalnız, mutsuz, kaygıll, umutsuz, bir şeyleri elden kaçırmanın pişmanlığını yaşayan, toplumsal normlarca örselenmiş, hırpalanmış, geçmişinde hayal kırıklıklarını ve terk edilmişlikleri barındıran muhtelif yaş gruplarına ait insanların serencamını anlatır. Başka bir deyişle, Eren'in öyküleri okura, aynı toplumsal yapı ve zaman diliminde yaşama tutunmaya çalışan "kırık hayatlar"dan, kendisini olduramayanlardan kesitler sunar. Bu açıdan Eren’in öykü karakterlerinin Oğuz Atay ve Halit Ziya Uşaklıgil’in içe dönük, nahif ve hayata tutunamayan kurmaca karakterleriyle paralellikler sergiledikleri söylenebilir.

Kitabın ilk bölümü olan "Gece"deki on bir öykü, fragmanlar şeklinde dönüşümlü olarak anlatılan ve mütemadiyen birbirine ulanan sekiz karakterin yaşamlarına odaklanır. Her öykünün bir nesne etrafında dönen, şekillenen gelişimi içinde Ilgaz’ın, Melike ve babası Tahir'in, Meryemana'nın, Ekrem'in, Şerife'nin, Seher ve oğlu İbrahim'in ortak bir mekân ve zaman üzerinden gelişen mutsuz, yalnız ve hayal kırıklıklarıyla dolu yaşamlarına tanık olunur.

Gaston Bachelard, muhtelif mekân türlerine odaklandığı Uzamın Poetikası adlı eserinde "ev"i "mutlu uzamın imgesi” (Bachelard, 2008: 43) bir mekân türü olarak değerlendirir. Ancak B. Nihan Eren’in öykülerinde ev, mutlu bir uzamın imgesi olmaktan bir hayli uzaktır. Aksine mutsuzluğun, yalnızlığın, korku ve kaygının, güvensizliğin, şiddetin kesintisiz bir şekilde yürürlükte olduğu kasvetli ve boğucu bir mekândır. "Portakal" öyküsünde anlatıcının dile getirdiği gibi Eren’in öykülerindeki "evler kara"dır (s. 54). Dahası öykü karakterlerinin yaşadıkları evlerin tavanından zemine doğru ilerleyen bir çatlaktan söz edilerek evlerin mutluluk ve güven vaat eden bir mekân olmaktan uzak olduğu simgesel düzlemde de dile getirilir. (“Çukur”, s. 74; “Ceviz”, s. 79). Öykü karakterlerinin umarsız yaşantılarına yakından bakınca bu durum bariz bir şekilde görülür. Söz gelimi, teknik üniversitede mühendislik okuyup ailesinin yüzünü kara çıkarmak istemeyen Ilgaz, öykü kişilerinin çoğunun meskun olduğu "Şenyuva” apartmanının karşısındaki bir apartmanın bodrum katında korku ve kaygılarla yaşar. Şimdisine hâkim kılmak istediği rasyonel düşünceyle, çocukluğunda ailesince kendisine belletilen batıl inançları arasında bocalar. "Teknik üniversitede bilimin, mekaniğin, rasyonelin peşine düşen Ilgaz, işte bir karga sesinde çarçabuk geçmişine dönenlerdendir" ("Kaçak Çay”, s. 10). Ilgaz’a göre dünya "soğuk ve tekinsiz" bir yerdir.

Ilgaz’ın, karşı apartmandan her akşam çlkarken gördüğü üzgün kız, Melike, üniversiteden mezun olduktan sonra hemşire olarak atanamamanın üzüntüsüne bir yalanı ve utancı da ekleyerek babası Tahir'le birlikte hayata tutunmaya çalışır. Aklı ve yüreği korku, şüphe ve utançla doludur. Babasından gizlediği çirkin bir gerçeği daha ne kadar sürdürebileceğinin telaşılla yaşar: "Melike'nin gözleri büyürken, babası anlamasın diye durdular. Yalanları bir güzel sıraladı Melike, seke seke yalanlara yalan kattı Melike, hiç utanmadı sıkılmadı Melike, hem annesine hem babasına hainlik etti Melike. Kapıyı kapattı. Merdivenlerden koşarak indi Melike. Yüzüne bir soğuk çarpınca utandı Melike. Allah onu affetsin." ("Hırka”, s. 32). Ancak Melike'nin günden güne artan suskunluk ve mahcubiyeti, babası Tahiri içli bir meraka ve şüpheye sürekler. Yazarın nesnelere ve Melike'nin tavırlarına incelikle yüklediği ayrıntılarla Tahir’in içini giderek kemiren bu şüphenin artık dayanılmaz bir raddeye ulaştığı bir akşam, anlamsız bir kuruntuya kapılmış olduğunu öğrenebilmek umuduyla kızının çalıştığını söylediği hastanenin acil servisini arayınca Melike'nin yalanı ortaya çıkar:

“'Melike Kuzu'yla görüşebilir miyim? Hemşire. Acil'de hemşire.' Ses ona beklemesini buyurdu. Tahir beklerken, midesi yandıkça yanıyor, dizleri titriyor, bütün bir hayattan, kızını anasız büyütüp okutmasından, onun hemşire çıkmasından, geceleri Melike'sinin hastaneye gitmesinden, derman ve

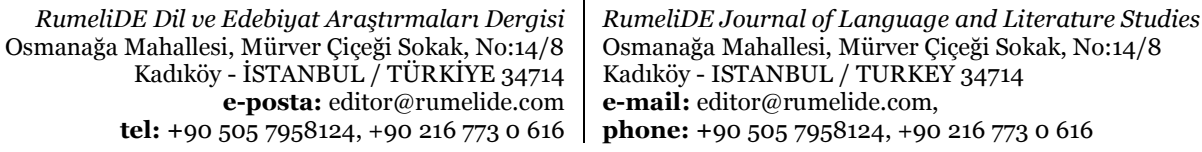


şifa vermesinden yine sevinmek, gururlanmak istiyor, sezgisi ve bu garip his ve korkuları için, bu açtı̆̆ı telefon için, hayattan ve biricik kızından özür dilemek istiyordu. Ses geri geldi. Burada o isimde biri çalışmıyordu" ("Hırka", s. 35).

Kendisinden gizlenen utancın bir yalan olduğunu öğrenebilmenin telaş ve umuduyla kızını sokaklarda aramaya çıktığı bir gece Tahir, bir yankesicinin silahından çıkan kurşunla öldürülür: "Karaltı bir piştov patlattı. Tahir’in uykusu geldi. Düştü. Yastığı sokaklar oldu” ("Hırka”, s. 35). Bölümün sonunda Melike, sebep olduğunu bilemeden, öğrenemeden, bir hastane morgunun önünde babasının ölümüne ağlar.

Coğrafya öğretmeni Meryemana ise kocası tarafından beklenmedik şekilde terk edilmenin üzüntüsüyle ve karnındaki çocukla hayata tutunmaya çalışır. Kötü olmasa da sıralaması yanlış bir hayatın dağdağası içinde yaşamını idame ettirebilmek için gündelik telaşelerle tek başına uğraşmak zorunda kalır:
"Meryemana o yazın yapış yapış öğle üstünde, askısı omzundan kaymış tişörtüyle banyodan çıkmış, uzun uzun ve soluksuz ağlamış ve bunu kimse bilmemişti. (...) Hayatın melankolik kederleri kocasının omuzlarındaydı. Sevinebilirdi. Meryemana'nın payına ise, gündelik telaşeler ile bir melodram düşmüştü. Ayakta kalma çabasının ağıllı̆̆l, okula gitmek ve günaydın demenin zorluğu, taşınmak ve bürokrasi, faturalar ve Pazar poşetleri, ağrıyan bel, bozulan musluk, patlayan ampul ve kanlı ve acılı bir doğum, Meryemana'nındı" ("Portakal”, s. 55).

"Şenyuva" apartmanının bir diğer sakini olan Seher, sürekli koca şiddetine maruz kalarak nesnesi hâline geldiği hayata mecburen "uyum sağlamaya" çalışır. Anlatıcı, "Ya yâr ya toprak olan kadınların diyarında" ("Portakal”, s. 54) Seher’in yaşadığı umarsızlı̆̆ı, çıkışsızlı̆̆ı mekân ve ona içkin nesneler üzerinden incelikle yansitır:

\begin{abstract}
"Kapı çalıyor, Seher kendine yine yaban oluyordu. Korkuyor ve kimselerini kaybediyordu. Seher buharlaşıp uçuyor, evin karanlığında kayboluyordu. Evler kara. Evler kara. Kapı tokmağı seher, yavaş yavaş döndü. Gelen içeri buyur edildi. Kapı önü yolluğu Seher’in, üzerine basıldı. Sonra sütlü kahve koltuk Seher'in üzerine oturuldu. Kahve istendi. Cezve Seher'in içine, iki kaşık Seher kahvesi kondu, karıştırıldı. Mutfak masası ve üstündeki elma kâsesi korkuyla sallanıyor, güzel günlerin ve mutlu bir evliliğin ümidini çoktan kaybetmiş olmanın yinelenen acısıyla kararıyordu. Çünkü evler kara. Tepsi Seher’in üstüne, ecel terinden köpüğü sinmiş bir fincan Seher kondu. Hiç gülmeyen o adama sunuldu. Dizinin her gece tekrarlanan bölümü, böylece başladı. Bir yumrukla devrilen tepsi Seher’in üzerindeki acı Seher kahvesi, güldallı Seher halısının üzerine bir nakış olup süzüldü” ("Portakal", s. 54).
\end{abstract}

"Babası gelince odasına kaçan çocuklardan" ("Çukur", s. 69) olan oğul İbrahim de bu şiddetten fazlasıyla nasiplenir. Her akşam renksiz ve tatsız bir dizi gibi tekrar eden bu şiddet anlarında İbrahim ders kitaplarının dünyasına sığınır ama bu sefer, yaşamın kendisine sunduklarıyla okul kitaplarında anlatılanlar arasındaki derin uçurumun kıyısında, annesine güzel bir gelecek sunmanın yükü ve ümidiyle aklı karışır. İbrahim’in yaşadıklarının manzaradan bir parça olduğu "Nasıl yaşanacağı bilinmeden, hasbelkader gelinmiş bir ömrün içinde, örselenerek büyümek, elbet İbrahim'e mahsus değildi.” (s. 73) cümlesiyle dile getirilir.

Şerife, okul okumak için birlikte yollandıkları büyük şehirde, köhne bir evde, babaanne Şerife gözetiminde hayata tutunmaya çalışır. Gündüzleri okulla, akşamları ise sıkıcı bir alışveriş merkezindeki parfümeride çalışmakla geçen Şerife, geceleri de artık iyice bebekleşen babaannesini avutmak zorunda olmanın yüküyle iyice bunalır. Hayata karışmak, özgürce ve dilediğince yaşamak arzusu, bunu nasıl yapabileceğini bilememenin deneyimsizliği ve tereddüdüyle sürekli örselenir. "Kimse yardımcı olmuyordu. Şerife'nin kim olacağını kimse söylemiyor, nerede ne söyleyeceğini kimse kulağına fısıldamıyor, içindeki sıkışmayla nasıl baş edeceğini kimse öğretmiyordu” (“Ceviz”, s. 78).

Adres $\mid$ Address

RumeliDE Dil ve Edebiyat Araşttrmaları Dergisi $\quad$ RumeliDE Journal of Language and Literature Studies Osmanağa Mahallesi, Mürver Çiçeği Sokak, No:14/8 Osmanağa Mahallesi, Mürver Çiçeği Sokak, No:14/8 Kadıköy - ISTANBUL / TÜRKIYE 34714 Kadıköy - ISTANBUL / TURKEY 34714 e-posta: editor@rumelide.com

e-mail: editor@rumelide.com

tel: +90 505 7958124, +90 2167730616 phone: +90 505 7958124, +90 2167730616 
Oğluna iyi bir baba olamamanın ve onu genç yaşta kaybetmenin kahrı ve pişmanlığıyla kıvranan Ekrem, televizyonun her daim sonuna kadar açtığı sesine sığınarak apartman sakinlerine yalnızlığını duyurur: "Aynada gördüğü, korkusuna korku katıp ecel terleri döktürünce Ekrem hemen döndü, televizyonu açtı. Sesini de yine sonuna kadar açıp yalnız olmadı̆̆ını kendine, yalnız olduğunu ise apartmandakilere gösterdi” (“Çakmak”, s. 82). Öykü kişilerinin yaşamak, katlanmak zorunda kaldığı bu durumlar, sinematografik bir kurguyla dönüşümlü ve kesitler hâlinde anlatılır. Anlatılan ev içi yaşantıların içerdiği boğucu ruhsal gerilime paralel şekilde öykülere hâkim atmosfer de kasvet ve karanlıkla bakışımlıdır. Bölümün adı da (Gece) zaten bu duruma işaret eder. Ama öykülerde kasvetin güdümündeki bu atmosferi yaratan tek şey karanlık (gece) değildir. Bu karanlığa, yağmur ve şiddetli bir rüzgâr da eşlik eder. Dolayısıyla Eren, öykü kişilerinin yaşamlarını kuşatan mutsuzluk, keder ve karamsarlığı, dış çevre ve nesne betimlemeleri yoluyla yarattığı karanlık ve kasvetin idaresindeki

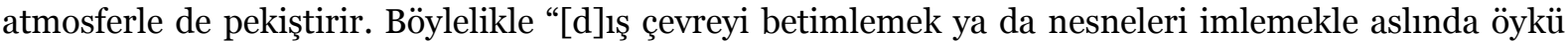
kişileri betimlenip belirtil[miş]” (Gümüş, 2012: 32) olur.

“Gün” başlı̆̆ını taşıyan ikinci bölümdeki dokuz öykünün de aynı ton ve atmosfere sahip olduğu söylenebilir. Anne-kız, anne-oğul, karı-koca, yalnız kadın ve erkeklerden oluşan bu bölümdeki öykü kişilerinin özel bir adı yoktur. Eren, yaşananların genelliğine işaret etmek için bu yola başvurmuş gibidir. Bu bölümdeki öykü kişileri de kanıksanmış bir umutsuzluk ve pişmanlıkla yüklüdür. Doğru ya da istendiği gibi yaşanamamış hayatların etkisiyle sürekli geriye, geçmişe bakan öykü karakterleri, bu yanlış hayatın sebepleri hakkında okura ipuçları sunar. Bu bölümdeki öyküler, mekân ve zaman olarak görece bir iyimserliğe sahiptir; güneşli ve denize nazır bir yaz günüdür ama bu iyimser atmosfer de kısa bir süre sonra meydana gelen şiddetli esinti ve denizin içeri doğru çekilmesiyle bir kâbusa dönüşür. Eren "birdenbire başlayan bir dalganın yani çeken akıntının tek tek karakterlerde nasıl bir etki bıraktığını yazarken aslında amacı[nın] içlerine dönerek hayatlarını anlamalarını yani hayatla hesaplaşmalarını sağlamak" (Toprak, 2020) olduğunu belirtir. Nitekim atmosferin içerdiği kırılgan iyimserlik, derhâl sakatlanır. Öykülerin kendi üzerine bükülerek, bir karanlığa kapanmasını yol açar. Kitaptaki her iki bölümün de bir ölüm vakasıyla noktalanması bu karanlığı enikonu belirginleştirir. Anlatıcı, ilk bölümde olduğu gibi, yine kesitler hâlinde ve birbiriyle kesişen bu mutsuz ve keşkelere ayarlı insanların yaşantılarını yer yer acı bir ironiyle aktarırken okura âdeta "Hayat işte!" demeye getirir. Öykülerde ele alınan odak temaları açımlamak için yazarın kitap boyunca tekrarlanan laytmotiflere başvurarak temel meselesini enikonu vurgulamaya çalıştığı söylenebilir (Tekin, 2003: 251). Muhtelif öykülerde dile getirilen "dizinin her gece tekrarlanan bölümü" ("Portakal", s. 55), "Her şey bir oyundu. Bir radyo tiyatrosu." ("Daire, s. 88), "Bunlar bir oyun. Oyun." ("Şemsiye”, s. 131) "Oyundu. Her şey yalnızca bir oyun. ("Şemsiye", s. 138) gibi ifadeler, böyle bir okuma yapmaya imkân verir. "Gece" ve "Gün" bölümlerinin girişlerinde epigraf olarak kullanılan, ilki Furuğ Ferruhzad'a ikincisi Birhan Keskin'e ait olan dizeler de işaret ettikleri hüzün ve sıkıntı duygularıyla öykülerin içerdiği bu tonal bütünlüğe imada bulunur.

Muhtelif bireylerin hayatları üzerinden anlatılan bu olumsuz manzaralar, öykülerin arka planında yer yer değinilen toplumsal düzenle koşutluklar taşır. Terry Eagleton'ın düşüncelerini uyarlayarak söylemek gerekirse, Eren’in öykü karakterleri, dâhil oldukları kamusal hayatın etkisinden muaf değillerdir. Kaçmak için uğraştıkları kamusal basıncı özel hayatları üzerlerinde fazlasıyla hissederler (Eagleton, 74: 2015). Eren, bu yolla öykü kişilerinin yaşadıklarının aslında sadece onlara özgü olmadığını ve toplumsal dokunun içerdiği görece olumsuzluklardan beslendiğini ima etmeye çalışır. Yazar, harcı şiddet ve önyargılarla karılmış bir toplumda birey olmanın da mutlu olmanın da zorluğuna işaret eder gibidir. Öykülerde anlatılanlar, bu olumsuz manzaranın bir kesitine mercek tutulduğunda görülen insanlar ve yaşamlardır. Eren’in eleştirel bakışı yürürlüğe koyduğu nokta da

\begin{tabular}{r|l} 
Adres & Address \\
RumeliDE Dil ve Edebiyat Arastirmaları Dergisi & RumeliDE
\end{tabular}

Osmanağa Mahallesi, Mürver Çiçeği Sokak, No:14/8 Osmanağa Mahallesi, Mürver Çiçeği Sokak, No:14/8

Kadıköy - İSTANBUL / TÜRKIYE 34714 Kadıköy - ISTANBUL / TURKEY 34714

e-posta: editor@rumelide.com

e-mail: editor@rumelide.com

tel: +90 505 7958124, +90 216773 o 616 phone: +90 505 7958124, +90 2167730616 
burada yoğunlaşır. Öykü kişilerinin mutsuz yaşamları, fondaki toplumsal durumun bir uzantısı olarak sunulur. Melike ve babası Tahir, her akşam televizyon karşısında tanık oldukları trajik olayların yaşandığı bir toplumda, yalanlarla bezeli küçük mutluluk anlarına sığınarak yaşama tutunmaya çalışırlar, ama tutunamazlar. Bölümün sonunda Melike, babasının ölümüne bilmeden sebep olmanın derin üzüntüsüyle yatağının içinde soğuk terler dökerek yapayalnız kalır. Bu soğuk ve tekinsiz dünyada Ilgaz, bütün bu olanlardan uzak durarak mühendis olup ülkesini sanayide ilerletmenin, mutlu bir yuva kurmanın, çocuklar yetiştirmenin ancak hayalini kurabilir. Bir parçası olduğu toplumun gerçeğini "görmemek için hep gözlerini yumacak" (“Kaçak Çay”, s. 15) olsa da vardığı nihai yer kaygı, telaş ve korku olacaktır.

Görünüşle gerçek arasındaki derin uçurum ve topluma hâkim ikiyüzlülük, Eren’in öykülerinde çok çarpıcı bir şekilde dile getirdiği ve eleştirdiği durumlardır. "Sigorta reklamlarında toprak kazan, ağ ören, deniz kenarında rahat ve uyumlu oturan güleryüzlü yaşlılar, bu siyatikli yılların ancak makyajı olabilir, ince bir kenar süsü. [Ekrem ve babaanne Şerife gibi] [g]erçeklerini ise dünya hep bir kenarda, bir salonda unutuveri[r]; hele ki bazı müzmin hastalıkları ve kederi hiç geçmemiş bazı acı hikâyeleri varsa kimilerinin, bir anda görünmez kılınır, paketleniverirler” ("Balık”, s. 39). Kitaplarda anlatılan üç tarafı denizlerle çevrili, yer altı ve yer üstü kaynakların zengini bir ülkede, İbrahim ve annesi her gece baba (erkek) şiddetine maruz kaldıkları bir “çoraklığa” katlanır. İbrahim’in yaşadığı bu çelişki, anlatıcı tarafından, "İnsan kendisine değil de yalnızca kitaplarına baksa pek makbul bir memlekette yaşadığını sanır." (“Çukur”, s. 72) cümlesiyle ironik şekilde dile getirilir. "Çukur" öyküsündeki şu sahne, eleştirinin nasıl incelikle yapıldığını göstermek için alıntılanmaya değerdir:

\begin{abstract}
“İbrahim bir çı̆̆lık duydu. Hemen okudu. Adana’nın denizden yüksekliği yirmi üç metre, nüfusu iki milyon yüz yirmi beş bin ve geçim kaynakları endüstri ve tarımdı. İbrahim küsüratlı iki milyon kişinin toprak sürdüğ̈̈nü, fabrika bacalarında tüttüğ̈̈nü düşünmeye çalıştı. Olmadı. Denize girip yüzdüklerini düşündü. Pamuklar denizdekilerin üzerine yağıyordu. Bunu sevdi. (...) Annesi yere düştü. Bağırdı. "Yapma” dedi. İbrahim okumaya devam etti. Giresun findık. Adana pamuk. Çanakkale anzak. Antep fistık. Tekirdağ ayçiçeği. Cizre linyit. Bursa ipek. Batman petrol. Edirne ciğer. Bilecik ceviz. İşte kitaplardaki Türkiyemiz” (s. 71).
\end{abstract}

Kadına yönelik geleneksel bakış açısı da öykülerin kadın karakterlerinin bilinci üzerinden yer yer dile getirilerek eleştirilir. "Terlik” öyküsünün "incelik ve azlık nedir bilmeyenlerden” (s. 169) olan kadını, kocası tarafından terk edilince iki erkek çocuğuyla birlikte yaşamak zorunda kalır. Bu durum, kadının çevresindeki insanların tatsız bakışlarına ve sorularına maruz kalmasına yol açar. Anlatıcı, bu noktada, kadına yönelik erkek egemen bakış açısının eleştirisini yürürlüğe koyar:

"Meraklılar. Sorular. Ona bunaltı verecek bir seyrin nesnesi olmaya hazır mıydı? Acıyacaklar ona. Suçlayacaklar. Dul ve namuslu oğlan anası gibi eteği diz altında dolanmasını isteyecekler, akşam karanlığında eve tıkılmasını bekleyecekler, hiçbir yerine hiçbir erkeğin değmediği bir çoraklık içinde mağrur ve tek başına uyumasını sessizce tembihleyecekler" (s. 172).

Birbirleriyle ve içinde yaşadıkları sosyo-kültürel dokuyla irtibatlı muhtelif karakterler üzerinden anlatılan bu olumsuz manzaralar yoluyla yazar, bütünlüklü bir toplumsal fotoğrafı dikkatlere sunarken eleştirel ve ironik anlatım tarzlarını ölçülü ve işlevsel bir düzeyde kullanır.

\title{
3. Bilincin sunumu
}

B. Nihan Eren’in öykülerindeki kurgu ve içerik uyumu, dil ve anlatım tutumuyla da desteklenir. Kör Pencerede Uyuyan, duru ama yoğunluğu elden bırakmayan bir dil ve anlatım tavrını yansitır. Kullanılan dil, öykü kişilerinin duygu ve düşünce durumlarına göre değişkenlik arz ederek çeşitlenir.

\begin{tabular}{r|l} 
Adres & Address \\
RumeliDE Dil ve Edebiyat Araşttrmaları Dergisi & RumeliDE Journal of Language and Literature Studies \\
Osmanağa Mahallesi, Mürver Çiçeği Sokak, No:14/8 & Osmanağa Mahallesi, Mürver Çiçeği Sokak, No:14/8 \\
Kadıköy - İSTANBUL / TÜRKIYY 34714 & Kadıköy - ISTANBUL / TURKEY 34714 \\
e-posta: editor@rumelide.com & e-mail: editor@rumelide.com, \\
phone: +90 505 7958124, +90 2167730616
\end{tabular}


Anlatıcı sadece dışardan gördüğü durumları anlatmaz, öykü kişilerinin bilincini de sözelleştirir, dile döker. Başka bir deyişle karakterin zihinsel söylemi anlatıcının söylemi kılığına büründürülür. Dolayısıyla, üçüncü tekil kişi anlatıcı tarafından anlatılanlar, aslında, söz konusu öykü kişisinin bilincinden yansıyanların da aktarımıdır (Cohn, 2008: 26). Bu paralelde, "Hırka" öyküsünde Melike'nin durumunu aktaran şu cümleler, aslında, onun zihninden de geçenlerdir:

\begin{abstract}
"Salona girdi. Pencere açıktı, tül perde uçuyordu. Melike şaşırdı. Babasının pencereyi neden açıp da bu soğukta kapamamış olduğuna şaştı. Hiç yapmazdı aslında böyle şeyler. (...) Babasını uyandırmak istemiyor, o uykularında rahat etsin istiyordu. Bu yalan değil bu gerçek. İki yıldır yalan söylüyordu evet ama sözleri yalan, hisleri gerçekti. Babasına kıyamıyor, o üzülmesin diye şaşıyordu. Hepsi bundandı" (s. 90).
\end{abstract}

Pasajda görülebileceği gibi Eren, üçüncü tekil anlatıcının aktarımlarıyla Melike’nin zihnine loş bir ışık tutar ve onun zihninden geçenleri, korku ve kayglarını dışa yansıtır. Anlatıcının dili bir tür maske işlevi görerek bu maskenin altından karakterin zihnine ait sesleri duyurur (Cohn, 2008: 116).

Benzer anlatım tarzı, “Gün” bölümündeki "SSemsiye” öyküsünün hayattan alacaklı ve ilgi düşkünü geçgin kadınının kumsalda yaptıklarının aktarımında da kullanılır. Söz konusu sahnede anlatıcı, serbest dolaylı anlatım tarzını kullanarak kadının zihnine ışık tutar; asıl kaygı ve beklentilerini hâlihazırdaki tavırlarının içine incelikle yerleştirerek yansıtır. Bu anlatım tarzı "sayesinde dünyayı karakterin gözünden ve onun sözleriyle görürüz; ama aynı zamanda yazarın gözünden ve onun sözleriyle de görürüz” (Wood, 2010: 22). Alabildiğine imalarla ve yoğun bir ironiyle kurgulanan sahne, Eren'in dil ve anlatım tarzının düzeyine işaret eder:

\begin{abstract}
"Kendi yitirdiklerine üzüldü. Ama işte böyleydi. Bu yüzden şemsiyenin sopasını kumlardan hafifçe çıkarttı. Şimdi koşacaklar. Birazdan yetişecekler. Ve eğlence işte tam burada başlayacak. Ay düşüyor. Şemsiye devriliyor. Ay nedense olmuyor. Kim, kim yapacak bunu? Kumların içine kim gömecek? Bunu buraya kim saplayacak? Kim derinlere sertçe ittirecek? Bastıracak. Hangi kol? Hangi bacak? Şimdi kim ona gölge edecek. İstediği ihsan buydu. Gölge. Ay vallahi yapamıyordu. Gelin. Burda bir kadın var. Koşun. Koşun. Bir şemsiyenin uzun demirini derine saplayamıyor. Yaşlanmiyor. Hâlâ genç. Yetişin.” (s. 132).
\end{abstract}

Sayısı rahatlıkla çoğaltılabilecek bu örnekler, B. Nihan Eren’in, öykü kişilerinin karakterine, kaygı ve beklentilerine uygun bir dil kullandığını, bu dilin öykülerin içeriği ve genel atmosferiyle de uyumlu olduğunu yansıtır. Anlatıma ritmik bir ton kazandıran kısa cümleleriyle, öykü kişilerini birkaç cümle içinde okurun zihnine çok net bir şekilde kazıyan ve Tanpınar üslubunu çağrıştıran "dönenlerdendir" (s. 10), "bilenlerdendir" (s. 12), "beceremeyenlerdendi" (s. 27), "inanamayanlardandı" (s. 29), "çocuklardandı" (s. 69), "olanlardandı" (s. 141), "anlamayanlardandı" (s. 152) gibi isim ve fiil çekimleriyle ve yer yer Madame Bovary’nin meşhur "Tarım Şenliği”" (Flaubert, 2001: 133) bölümünü anımsatan polifonik / çoksesli sahneleriyle ("Şişme yataklı!!! Şişme yataklı!!" "Sepet”, s. 118) Eren’in çok tartımlı ve ölçülü bir dil ve anlatı senfonisi yarattığını söylemek mümkün.

\title{
Sonuç
}

Genç kuşağın dikkate değer öykücülerinden biri olarak öne çlkan B. Nihan Eren’in Kör Pencerede Uyuyan adlı öykü kitabı kurgusu, içeriği, dil ve anlatım kullanımıyla dikkate değer öyküler içerir. Kitaptaki öyküler, bilinçle kurgulanmış ve birbirine sıkıca bağlıdır. "Gece" ve "Gün" adlı iki farklı bölüm söz konusu olsa da bütün öyküler, müşterek bir zaman diliminde ve mêkanda geçer. Zaman ve mekân konusundaki bu kesişmeler, yazar tarafından kimi öykülerde açık kimi öykülerde ise daha örtük bir şekilde yapılır. Her öykünün önceki veya sonraki öykülere ustaca bağlanması, Eren’in kurgulama konusundaki yetkinliğini bir üst perdeye taşır. Salt dekor veya atmosfer malzemesi olarak kullanılan

\begin{tabular}{|c|c|}
\hline & \\
\hline eliDE Dil ve Edebiyat Araşttrmaları De & E Journal of Language and Literature Studies \\
\hline 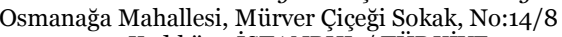 & Mahallesi, Mürver Çiçeği Sokak, No:14/8 \\
\hline Kadıköy $-\mathrm{I}$ & ISTANBUL / TURKEY 34714 \\
\hline $\begin{array}{r}\text { e-posta: editor } \\
\text { tel: }+905057958124,+9\end{array}$ & $\begin{array}{l}\text { editor@rumelide.com, } \\
\text { +90 505 7958124, +90 } 2167730616\end{array}$ \\
\hline
\end{tabular}


nesne ve ayrıntıların Eren’in öykülerinde kurguyu ve insan ilişkilerini anlamaya imkân veren bir işleve sahip olduğu görülür. Öykülerin doğal ritmini ve akışını bozmayan bu bağlantı noktaları dikkatle okunduğunda fark edilebilir. Dolayısıyla Eren’in, Kör Pencerede Uyuyan'daki öykülerde okura dikkat ve çaba talep eden bir kurgu sunduğu söylenebilir.

Yalnız, umutsuz, mutsuz, kaygıll, pişman, toplumsal normlarca örselenmiş, hırpalanmış, geçmişinde hayal kırıklıklarını ve terk edilmişlikleri barındıran muhtelif insanların yaşamlarına ilişkin kesitler, kitaptaki öykülerin muhtevasını oluşturur. Başka bir deyişle, Eren’in öyküleri, aynı toplumsal yapı ve zaman içinde hayata tutunmaya çalışan "kırık hayatlar"dan kesitler sunar. Bu bireysel hayatlar üzerinden aktarılan kesitlerin, toplumsal arka planla son derece uyumlu olduğu görülür. Bireysel düzlemde yaşanan sıkıntıların kolektif bir dip akıntıdan, öykülerin içerdiği toplumsal dokuya hâkim olumsuz manzaradan beslendiğini Eren her firsatta okura ima etmeye çalışır. Kitapta, kötülüğün fark edilemeyecek kadar sıradanlaştığı bir toplumda mutlu ve geleceğe güvenle bakan bir birey olmanın zorluğuna işaret edilir. Eren, bu olumsuzlukların bir kesitine mercek tuttuğunda gördüğü insanları ve yaşamları etkili bir dil ve anlatımla kurgu düzlemine aktarır. Öykülerde, görünüşle gerçek arasındaki derin uçurum, topluma hâkim ikiyüzlülük ve kadına yönelik geleneksel bakış açısı yazarın çok çarpıcı bir şekilde eleştiri oklarını yönelttiği diğer temel konular olarak öne çıkar. Eren’in öykülerindeki dil ve anlatım tutumu da bu kurgu ve içerikle bütünleşen bir yapı arz eder. Anlatılan duygu ve düşünce durumlarına göre dinamik bir yapı sergileyen öykü anlatıcıları, karakterlerin bilincine sızarak onların zihinsel söylemini anlatıcının söylemi kılı̆̆ına büründürür. Bu açıdan Eren'in modern anlatım tekniklerini öykülerinde bilinçle ve başarıyla uyguladığı söylenebilir.

Yapılan incelemeden de anlaşılacağı üzere Eren’in öyküleri, nitelikli bir okuma ve anlama uğraşı için ilk okumadan çok daha fazlasını gerektiren kurgusal bir derinliğe, ayrıntı zenginliğine, özgün bir dil ve anlatım tutumuna sahiptir. Çünkü okurun zihnine, her öyküyle birlikte yeni sorular düşürebilme potansiyeline sahiptir. B. Nihan Eren’i çağdaş Türk edebiyatının dikkate değer öykü yazarlarından biri olarak öne çıkaran da öykülerinin kurgu, içerik, dil ve anlatım yönlerinden sahip olduğu bu bütünlük ve uyumdur. Bu çerçevede Kör Pencerede Uyuyan adlı öykü kitabının, yazarın öykücülügünün dönüm noktalarından, belirtisel örneklerinden biri olduğunu söylemek gerekir.

\section{Kaynakça}

Bachelard, G. (2008). Uzamın Poetikası. (Çev. Alp Tümertekin). İstanbul: İthaki.

Cohn, D. (2008). Şeffaf Zihinler-Kurmaca Eserlerde Bilincin Sunumu. (Çev. Ferit Burak Aydar). İstanbul: Metis.

Çobanll, I. (2015). "Kör Pencerede Uyuyan Öyküler". BirGün. Erişim Tarihi: 21.11.2020, https://www.birgun.net/haber/kor-pencerede-uyuyan-oykuler-76645.

Eagleton, T. (2015). Edebiyat Nasıl Okunur. (Çev. Elif Ersavcı). İstanbul: İletişim.

Eren, B. N. (2015). Kör Pencerede Uyuyan. İstanbul: Yapı Kredi.

Flaubert, G. (2001). Madame Bovary. (Çev. Tahsin Yücel). İstanbul: Can.

Gümüş, S. (2012). Öykünün Bahçesi. İstanbul: Can.

Koyuncu, İ. (2019). “B. Nihan Eren”. Türk Edebiyatı İsimler Sözlüğü.

Moran, B. (2007). Edebiyat Kuramları ve Eleştiri. İstanbul: İletişim.

Tekin, M. (2003). Roman Sanatı 1. İstanbul: Ötüken.

Toprak, E. (2020). "Hayal Otel”. B. Nihan Eren ile Söyleşi. Cumhuriyet. Erişim Tarihi: 20.11.2020, https://www.cumhuriyet.com.tr/haber/hayal-otel-1771387.

\footnotetext{
Adres $\mid$ Address

RumeliDE Dil ve Edebiyat Araşttrmaları Dergisi $\quad$ RumeliDE Journal of Language and Literature Studies Osmanağa Mahallesi, Mürver Çiçeği Sokak, No:14/8 Osmanağa Mahallesi, Mürver Çiçeği Sokak, No:14/8 Kadıköy - ISTANBUL / TÜRKIYE 34714 Kadıköy - ISTANBUL / TURKEY 34714 e-posta: editor@rumelide.com e-mail: editor@rumelide.com, tel: +90 505 7958124, +90 2167730616 phone: +90 505 7958124, +90 2167730616
} 
380 / RumeliDE Journal of Language and Literature Studies 2021.23 (June)

A study on B. Nihan Eren's storybook Sleeping in the Blind Window / M. Karadeniz (pp. 369-380)

Tosun, N. (2011). Modern Öykü Kuramı. Ankara: Hece.

Tosun, Y. (2008). "Kasaba Havası". Notos Öykü. 13, 136-137.

Uçmaner, M. (2020, 8 Haziran). "Otel Hayal, Edebiyat Gerçek”. Birgün Kitap.

Wood, J. (2010). Kurmaca Nasıl İşler (Çev. Ekin Bodur). İstanbul: Ayrıntı. 